\title{
Ankara'da Eşkıya Tarafından Gerçekleştirilen Vakıf Gayrimenkullerinin Tahribatı Hakkında Bazı Görüşler(XVII. ve XVIII. Yüzyıllar)
}

\author{
Some Ideas on the Damage of Foundation Property Caused by Bandit Groups in Ankara \\ (XVII. and XVIII. Centuries)
}

\section{Ahmet KÖÇ}

Tarih Bölümü, Fen Edebiyat Fakültesi, Balıkesir Üniversitesi, Balıkesir, Türkiye

\section{Özet}

XVI. yüzyıl sonlarında başlayan Celâlî olayları, XVII. yüzyııın ilk yarısında da devam etmiştir. Anadolu'da güvenlik boşluğu oluşturan Celâlî olayları sırasında hem şehir merkezlerindeki binalar yakılıp yıkılmış hem de kırsaldaki tarım faaliyetleri engellenmiştir. Ankara Sancağı, şehir merkezi ve kırsalıyla bu olaylardan büyük zarar görmüştür. Eşkıyanın Ankara'da kazandığı bu konum, daha sonraki dönemlerde sürüp sürmediği incelenmeye muhtaçtır. Karen Barkey eşkıyalığın Osmanlı devlet merkezileşmesine dolaylı katkı yaptığı fikrini savunduğuna göre, bu grupların devletle sürdürdükleri iletişimin boyutlarını anlamak gerekmektedir. XVII. yüzyılın ilk yarısında şehirde konumunu güçlendiren eşkıya gruplarının sonraki yüzyılda neden eskisi gibi hakimiyetini sürdüremediği, vakıf mülklerine zarar veremediği, geri çekilerek daha çok yol eşkıyalığına yöneldiği sorularının cevaplanabileceği temel kaynak türlerinden biri şer'iye sicilleridir. Çalışmada bahsedilen yüzyıllarda eşkıya gruplarının Ankara'da vakıf topraklarında ve gayrimenkullerinde oluşturduğu tahribat, şer'iye sicilleri üzerinden yorumlanmaya çalışılacaktır.

Anahtar Kelimeler: Osmanlı, Ankara, vakıf, eşkıya, Celâlî isyanları

\begin{abstract}
Although human beings introduced foundations, the foundations are still among the works of art that human beings have harmed. Jelali events started in the end of XVI. century and continued in the first half of XVII. century. During Jelali events that caused security vacuum in Anatolia, both buildings in city center were demolished and agricultural activities in rural areas were prevented. Ankara Sancak, together with the city center and the rural areas was seriously damaged by these events. It is necessary to research whether the power that the bandits won in Ankara continues in later periods or not. Now that Karen Barkey stands up for the idea that banditry contributed to the Ottoman centralization, it is necessary to understand the dimensions of the communication that these groups had with the government. One of the basic resource types that can answer to the questions of why the banditry groups that gained power in the city centers in the first half of XVII. century couldn't maintain its dominance in the following period, couldn't harm to the foundation property, withdrew an and focused more on the road bandits is court records (şer'iye records). The damage that bandit groups caused in Ankara foundation areas and real estates in the centuries mentioned in the study will be tried to be commented on by using court records.
\end{abstract}

Key Words: Ottoman, Ankara, foundation, bandits, Jelali revolt 


\section{Giriş: Çalışmanın Sınırları}

Şer'iye sicillerinden hareketle hazırlanan bu çalışmada; özellikle Ankara şehrinin XVII. yüzyıl başlarından, XVIII. yüzyıl sonlarına kadar geçen iki asırlık süredeki vaziyeti ele alınmaktadır. Çalışmada ön plana çıkarılmaya çalışılan iki yön vardır. Birincisi Ankara'nın XVII. yüzyıl başlarından XVIII. yüzyıl başlarına kadar geçen sürede şehre ait belgelerini sunmak ${ }^{1}$, ikincisi Osmanlı taşrasında düzeni ihlal eden eşkıyanın vakıflara verdiği zararları ortaya koyarak bu tabloyu yüzyıllara göre yorumlamaktır².

Şehirlerdeki kurumlar, sosyo-ekonomik yapılar, şehri etkileyen deprem, yangın ve isyanlarla ilgili bilgi kaynaklarımızın başında şer'iye sicilleri gelmektedir. Çünkü ister isyan, isterse bölge ileri gelenlerinin baskı/zulmü şeklinde olsun, vakıflarla ilgili her türlü ihlal; doğrudan İstanbul'a intikal ettirildiği için fermanların yazılmasına sebep olmuştur. Bu yüzden merkezden gönderilen belgeler ahalinin birbirleriyle olan ilişkilerini ve devlet karşısındaki durum ve tutumlarını gösteren belgeleri de kapsamaktadır. Dolayısıyla şer'iye sicillerini incelemeksizin Osmanlı şehirleri ve müesseseleri hakkında sağlıklı bilgiler elde etmek mümkün değildir.

Şer'iye sicilleri ışığında Ankara tarihini incelemeye geçmeden önce bir takım bilgileri vermek gerekmektedir. Çalışmada şer'iye sicilleri kullanılacağ $\breve{1}_{1}$ için Ankara'nın ilk şer'iye sicili, H.990-91/M.1583-4 yıllarına aittir. Bu çerçevede araştırmanın başlangıç noktasını H.990-91/1583-84, bitiş noktası ise H.1215/M.1800 yılı olacaktır. Belirtilen tarih aralığında Ankara'nın 193 şer'iye sicili vardır. Çalışmada döneme ait şer'iye sicilleri incelenerek, eşkıyalıkla ilgili belgeler tespit edilmiştir ${ }^{3}$. Tespit edilen belgelerin hepsini bu çalışmada kullanmak mümkün olmadığından -kaynakçada da görüleceği üzerevakıf eşkıyalığıyla ilgili 49 sicilden ve arşiv kayıtlarından faydalanılmıştır.

XVI. yüzyıl sonlarına doğru tımar kadrolarının dolmaya başlaması, askerî anlamda toplumsal hareketliliğin önünün kapandığının işaretidir. Tımar sisteminin çözülmeye

\footnotetext{
${ }_{1}^{1}$ Ankara'nın neden seçildiği sorusuna gelince; Ankara, Orta Anadolu'da önemli bir şehirdir. İklim açısından karasal ve az yağış alan bir bölgede bulunmaktadır. Ankara şehri, Anadolu yolları bakımından kuzeygüney; doğu-batı yollarının kavşağındadır. Öte yandan Ankara şehir merkezinde ve civarında ticarî hareketliliği arttıran önemli bir sektör vardır. Osmanlı ticarî hayatında tiftikten yapılan sof dokumaları o dönemde uluslararası ticaretin kıymetli ürünlerinden birisidir.

${ }^{2}$ Anadolu'da görülen eşkıyalığı sosyal bir olgu olarak ele alan çalışmalar vardır. M. Akdağ, H. İnalcık, M. Ç. Uluçay, K. Barkey ve W. J. Griswold'un çalışmaları oldukça önemlidir. Bunların dışında başka çalışmalar da yapılmıştır. Ancak yapılan bu çalışmaların çok azında eşkıyanın vakıf kurumlarına verdiği zarardan bahsedilmiştir. Eşkıya gruplarının Ankara'daki vakıflara verdiği zararı Muhammed Ceyhan, Ankara Şer'iye sicillerine göre incelemiştir. Ceyhan'ın, Celâlı İsyanlarının Ankara Vakıf Gayrimenkulleri Üzerinde Yarattığı Tahribatın Tesbiti(Şer'iye Sicilleri Işı̆̆ında) isimli çalışması, beş şer'iye sicili üzerinden hazırlanmıştır. Araştırmacının Tarihte Ankara Uluslararası Sempozyumu'nda sunduğu bu bildiri, kapsam olarak daha dar bir dönemi ele almaktadır. Öte yandan Efkan Uzun'un, Osmanlı Ülkesinde Görülen İsyan ve Eşkıyalık Olayları Karşısında Alınan Bazı Tedbirler Hakkında Bir Değerlendirme isimli makalesi vakıf mülklerini tahrip eden eşkıyadan çok fazla bahsetmemektedir.

${ }^{3}$ Ankara Şer'iye sicillerinin hemen hepsinde eşkıyalıkla ilgi en az üç-beş belgeye rastlamak mümkündür. Sicillerde sadece şikâyetler değil, aynı zamanda eşkıyalıkla ilgili emirler de vardır. 193 defter içerisinde özellikle XVII. yüzyılın ilk yarısını kapsayan defterler detaylı olarak incelenmiştir. Çünkü bu dönemde daha önce az görülen olaylar, sürekli olarak görülmeye başlamıştır. Diğer taraftan eşkıyalık hareketlerinin vakıf gayrimenkullerine verdiği zararların karşılaştırmalı olarak ele alınabilmesi için XVIII. yüzyılın da araştırmaya dahil edilmesi gerekmiştir.
} 
başlaması, Celâlî olaylarını arttırmıştır. Anadolu'da Celâlî olayları, toplumun yaşantısını, düzenini derinden etkilemiştir. Bir tarafta toprak düzeninin bozulmasına işaret eden Celâlî olayları, diğer tarafta sonraki yüzyılda değişimin bütün devleti kapsar şekilde yerel otoriteyi dönüştürmeye başlamasıyla âyanlık sistemi doğmuştur. Âyanlığın ortaya çıkışı, Osmanlı klasik dönem teşkilatının çözülmeye başlamasına taşradaki güçlerin yükselişine tanıklık etmektedir. $O$ halde âyanlık dönemindeki eşkıyalık olaylarından vakıf kurumları ne derece etkilenmiştir? Sorusu ikinci kısmın temelini oluşturacaktır. XVIII. yüzyılda hemen her bölgede eski devlet memurları güç ve nüfuz elde ederek toplumu yönlendirmeye, şehirler üzerinde otorite oluşturmaya başladıklarına göre -Celâlî isyanları döneminde olduğu gibi- vakıflar üzerinde baskı unsuru olan gruplar var mıdır? Soruları cevaplanmalıdır. Bu yüzden Celâlî olaylarından başlayıp, âyanlığın gelişmesine kadar giden süreçte eşkıyaların Ankara'daki vakıflar üzerinde ne tür tahribat yaptıklarını yüzyıllara göre değerlendirmek gerekmektedir.

Konunun sinırlarıyla ilgili tekrar bir çerçeve çizmek gerekirse, burada Ankara bölgesindeki vakıf binalarına veya vakıf arazilerine zarar veren eşkıyalardan bahsedilecektir. Ankara şehir merkezinde ve kırsalında gerek küçük gruplar halinde, gerekse büyük gruplar halinde her zaman haydutlar görülmüştür. Şer'iye sicillerinden hareketle olaylara bakıldığında, eşkıyalık meselesinin Osmanlı Anadolu'sunun bir gerçeği olduğunu, bazı dönemlerde daha seyrek, bazı dönemlerde ise daha yoğun şekilde ortaya çıtıkları anlaşılmaktadır. Çalışmada önce Celâlî olaylarının ortaya çıkışı ve bunların vakıflara verdikleri zararlar üzerinde durulacak, sonra ise Âyan, Eşraf, Türkmen, Yörük, Ekrad gruplarının oluşturduğu yol eşkıyalığı sırasında vakıf mülklerinin durumuna değinilecektir

\section{a-Celâlî Olayları Sırasında Ankara}

Kaynaklarda hukukî olarak; yol kesen, haydut ve haramilik yapan kişiler için eşkıya kelimesi kullanılmıştır. Bu kelime; yol kesenlerin yanı sıra daha çok şakî(çoğulu eşkıya), Celâlî, eşirra, haramî, haramzâde, türedi, haydut ve uğru terimlerini de içermektedir. Eşkıyalığın ortaya çıkış süreci, içinde bulunulan şartlarla yakından ilgilidir. XVI. yüzyılda giderek tırmanan ve XVII. yüzyılda büyük bir problem haline gelen eşkıyalıkta nüfus artışı, halkın fakirleşmesi, ticari faaliyetlerin yoğunlaşması ve siyasî iktidarların zaafa uğramasının etkisi vardır. XV. yüzyılda Anadolu'da küçük çeteler görülüyor ise de bu durum hiçbir zaman büyük bir yıkıma yol açmamıştır. Kanuni Sultan Süleyman devrinde yeniçeri askerlerinin sayısı artmış, devşirme ocağında bozulma başlamıştır. Bu süreçle bağlantılı olarak nüfusun hızla çoğalması ve çift bozanlığın artması, köylerini terk eden gençlerin teşkil ettiği sekban-saruca(levend) gruplarının sosyal ve idarî düzeni tehdit etmeye başlaması, huzursuzluğu arttırmıştır. Aynı yıllarda silah teknolojisinin gelişmesiyle birlikte XVI. yüzyıl sonlarında ateşli silahları kullanmayı bilen kişiler ön plana çıkmaya başlamıştır (Öz, 2009: 38; Uzun, 2009;195).

Tımarlı sipahilerin ihmal edilmeye başlaması köy kökenli gençleri kanunsuzluğa yöneltmiştir. Öte yandan mali sistemde devletin hazine gelirlerini arttırmak için tımar sisteminden iltizam sitemine doğru kaymaya başlaması, gelirlerin yarıdan çoğunun mültezimlerden nakit alınabilir duruma getirmiştir. Bunların yanı sıra mültezimlerin halktan daha fazla vergi toplamaya yönelmesi huzursuzluk sebeplerinden biri olmuştur. 
Sekban ve sarıca askerlerinin hem yeterli ücret alamadıklarını bahane ederek reaya üzerinde baskı kurması, hem de savaş sonraları terhis edilmeleri onların eşkıyalığa yönelmesine yol açmıştır. XVI. yüzyıl sonlarından XVII. yüzyıl başlarına kadar olan sürede yoğun olarak görülen celali isyanlarında bu grupların büyük etkisi vardır (İnalcık, 1980: 48; Tabakoğlu, 1985: 213).

Celâlîlerin bu dönemde oluşturduğu korku ve endişe, şehir merkezlerinde ve kırsal bölgelerde kargaşa nedenidir. Eşkıya gruplarının kırsal alanlardaki yerleşim yerlerine, reayaya veya vakıflara ait gayrimenkullere yaptıkları saldırılar, sığınacak güvenli yer arayan halkın şehirlere doğru göçlerini hızlandırmıştır. Kargaşa sırasında şehir halkı ise yakınında bulunan kaleye çekilmiştir. Şehir merkezinde ikamet eden halk, kırsal bölgelerde yaşayan halka göre biraz daha şanslıdır. Örneğin Ankara'da şehrin yüksek kesiminde güvenliği sağlam kapılarla sağlanan korunaklı bir kale mevcuttur. Sağlam bir kalesi olmasına rağmen Ankara halkı kendi imkânlarıyla kentin etrafını surlarla çevirmiştir.

Celâlî karışıklığı sırasında etrafı surlarla çevrili güvenli kaleler bulamayan köylüler, güvenlik ihtiyaçlarını karşılayabilmek için kendilerine göre çözüm yolları geliştirmişlerdir. Bu çözüm yollarından ilki; kırsal bölgelerde yaşayan köylülerin, Celâlî eşkıyalığı başlayınca mal ve mülklerini bırakarak göç etmesidir. Kaynaklara göre Amasya'daki sultan II. Bayezid Vakfı'nın Murtazaabâd Kazası'na bağlı İstanos ve Erkeksu Köyleri halkının bir kısmı göç etmiş, diğer kısmı ise köylerde kalmayı sürdürmüştür. Köyde kalanların uzunca bir süre eşkıya baskısı altında kaldıkları, gelirlerine el konduğu yaptıkları şikâyetlerden anlaşılmaktadır (AŞS. 21/707:1451). Bu vakıf reayasından olup topraklarını terk eden 22 gayr-1 müslim aile, Ankara şehir merkezine yerleşmişlerdir. Aynı tarihlerde Amasya'da bulunan Sultan II. Bayezid Vakfı'nın mütevellisi ise tarımsal faaliyetleri bırakıp Ankara şehir merkezine göç eden vakıf reayasının köylerine geri dönmesi için 24 Cemâziye'l-evvel 1031/6 Nisan 1622 tarihinde mahkemeden talepte bulunmuştur (AŞS. 20/706: 230). Bu konuyla ilgili başka bir kayılt ise 7 Safer 1021/9 Nisan 1612 tarihlidir (AŞS. 20/706: 238). Belgede Ankara havalisinden kaçıp gelen köylülerin, şehir civarındaki vakıf topraklarına girdikleri ve buraları işgal ettikleri yönündedir. Esasında bölgede faaliyet gösteren eşkıyanın amacı, reayanın kendisine destek vermesini sağlamaktır. Dolayısıyla reaya açısından bakıldığında eşkıyanın taleplerine olumlu cevap vermeyenlerin cilâyı vatan/terk-i diyar etmekten başka çaresi de yoktur.

3 Rebîü'l-âhir 1021/3 Haziran 1612 tarihinde ise Ankara'da medfûn Hacı Bayrâm-1 Velî halifelerinden Haymana-i Kebîr Nahiyesi'ndeki Kutluhan nâm karyede bulunan Şeyh Hüsameddin Zaviyesi'nin nice zamandır istilâ-i Celâlî ile hal̂̀ kaldığı belirtilmiştir. Zaviyenin faaliyet göremez duruma gelmesi, buradaki dervişlerin dağılmasına yol açmıştır. Bu durumda vakıf şeyhinin oğulları belirsizliği azaltmak amacıyla vakıf arazilerini işleyerek gelir temin etmek istemişlerdir. Nitekim şeyhin oğulları Derviş

\footnotetext{
${ }^{4}$ Ankara halkının; Tavil Mehmed'den ayrılan eşkıyâ havfindan kendü malları ile sûr binâ ettikleri belirtilir (AŞS.10/696:1481). Diğer taraftan 4 Cemâziye'l-âhir 1015/7 Ekim 1606 tarihinde ise Kalenderoğlu isimli eşkıyanın beş gün süren saldırısında halk, kalede kapalı kalmıştır (AŞS. 10/696: 320). Şehir halkı, 1604 yılında Karakaş, 1605 yılında Celâlî Hasan ve 1606 yılında Kalenderoğlu'na karşı başarılı bir savunma gerçekleştirmiştir (Ergenç, 1995, 78).
} 
Mustafa, Hüsameddin ve İdris vakıf arazilerini tekrar ekip biçmek için berat talebinde bulunmuşlardır (AŞS. 14/700: 1100). Aynı tarihlerde Ankara şehri kırsalında bulunan İsa Bey Fenârî Vakfı'nın Yakacık, Gökçeköy ve Kapaklı köylerindeki gelirleri reayadan toplanamamıştır (AŞS. 51/737: 588). Ankara kırsalı ile ilgili verilen bu örnekler, Celâlî karışıklığının vakıf topraklarında oluşturduğu tahribatı gözler önüne sermektedir.

Merkezî otoritenin sarsıldığı bir geçiş döneminin sonucu olan Celâlî olayları, o döneme kadar görülmemiş büyük eşkıya gruplarını bir araya getirmiştir. Sayıları hızla artan Celâlî grupları, kendi çıkarları için uygun gördükleri yerleri yağmalamışlardır. Bu dönemde bölge yöneticileri, şehir merkezlerinde ve köylerde otoriteyi tam olarak sağlayamamışlardır. İsyancılar yağma yaptıkları sırada kendilerine karşı gelen, zorluk çıkaran kişileri de cezalandırmışlardır. Neticede Celâlî grupları şehirlerdeki otorite boşluğundan faydalanarak reaya üzerinde korku ve endişe oluşturmuş, onları baskı altında tutmuştur.

Celâlî olayları sırasında Ankara şehir merkezinin durumunu ortaya koyan sicil kayıtları da vardır. Örneğin 1607 yılında Ankara halkı şehir kadısına gelerek, eşkıya saldırıları nedeniyle halkın dağıldığını belirtmiştir. Bu dönemde şehir halkının üçte birinin yer değiştirdiği düşünüldüğünde; halkın temel beklentisi mahallelerdeki nüfus yapısına göre avârız hanelerinin yeniden hesaplanmasıdır. Zira, Ankara Kazası'ndaki mahallelerin nüfus yapısının değişmesi, reayanın avarız yükümlülüğü ile ilgilidir ${ }^{5}$.

Sicil kayıtlarına göre Celâlî olaylarının kırsal bölgelerde olduğu gibi Ankara şehir merkezin deki vakıf mülkleri üzerinde de derin izleri vardır. Nitekim 10 Zilka'de 1020/14 Ocak 1612 tarihli belgede Hasan Paşa Vakfı mütevellisi Abdi b. Mustafa mahkemeye gelerek Karakaş Celâlî́ ${ }^{6}$ ve adamlarının yaktığı hanın yeniden tamir ve termimi için 50.000 akçeyi kadı huzurunda teslim etmiştir (AŞS. 13/699: 402). Daha sonra Hasan Paşa'nın Sulu Han'ı için yapılan yeni keşifte inşaat masrafı 60.980 akçe olarak gösterilmiştir (AŞS. 13/699: 667). Bu dönemde hanın, bitmeyen kısımları için vakıf cabisi Hasan b. Emir, 3.000 akçelik ilave para talebinde bulunmuştur (AŞS. 15/701: 54). Görüldüğü üzere Celâlî eşkıyası şehirde yoğun olarak kullanılan mekânlara yönelerek kendini kabullendirmeye çalışmıştır.

Adamlarıyla birlikte şehre gelen ve şehri ateşe veren Karakaş Celâlî, Ankara çarşısında Yeğen Bey Vakfı'nın dükkânını da yakmıştır . Vakıf mütevellisi Edhem b. Mustafa vakıf dükkânının tamiri ve yeniden kiraya verilmesi için 30 akçe icâre-i muaccele $^{8}$ talep etmiştir (AŞS. 15/701: 54). XVII. yüzyıl başlarında yıkılmış vakıf

\footnotetext{
${ }^{5}$ Vergiye esas taban kabul edilen bir avarız hanesi genellikle 3 ile 15 hane halkından teşekkül ederdi. Eğer hane halkları zengin ise az yazılır, fakirse sayıları arttırılırdı. Kriz dönemlerinde ise avarız sayıları arttırılabilirdi. Bk. N. Göyünç, “Hane Deyimi Hakkında”, Tarih Dergisi XXXII, s.347.

${ }^{6}$ Karakaş Celâlî şehre girdiğinde şehirdeki işler durmuştur. Belgede; on yedi gün mahkeme-i şerîfe açılmayub, kal'ada muhasara olunmağın mesâlih-i müslimîn görülmeyib muattal kaldığı belirtilmiştir (AŞS. 9/695: 288).

${ }^{7}$ Vakıf dükkânların yanması bu binalar içinde ticaret yapanları da etkilemiştir. Mahmud b. Hüseyin borcu olan ü̧̈ vukıyye ipliği zımmî Hubî’ye ödeyememiştir. Borçlu Mahmud; Safer ayında Celâlî geldikte aldılar. Kal'aya çıkaramadım idi diyerek kendini savunmuştur (AŞS. 9/695: 438).

8 İcare-i Muaccele, icareteyn uygulamasındaki kira bedelinin peşin ödenen kısmı olduğundan, buna peşin kira da denir. Peşin kira genellikle vakıf emlakinin gerçek değerinin yarısına eşit olup, bunların tamirine harcanması gereken meblağdır (Yediyıldız, 2003: 136).
} 
mülklerinin yeniden sektöre kazandırılabilmesi için yıkılan binaların tamiri karşılığında kiraya verilebilmesi için icâreteyn usûlü ${ }^{9}$ geliştirilmiştir (Ceyhan, 2012: 371).

15 Şevval 1032/Temmuz-Ağustos 1623 tarihli belgede ise Ankara Kalesi Dizdarı merhûm Musa Ağa Evkafı'nın mülklerinin zarar gördüğü ifade edilmektedir. Vakıf mütevellisi el-Hâc Hasan b. Abdurrahman; Yorgancılar Çarşısı'ndaki iki adet dükkanın Celâlî olayları sırasında yakıldığını ve 20 seneden beri kullanılamadığını ifade etmiştir ${ }^{10}$. Ankara Çarşısı'ndaki dükkanların birbirine bitişik vaziyette olması, Celâlî isyanlarında büyük bir kısmının kısa sürede yanarak yok olmasına yol açmıştır.

23 Receb 1033/14 Mayıs 1624 tarihinde ise Abaza Mehmed Paşa isyan ederek askerleriyle birlikte Ankara şehrine gelmiştir ${ }^{11}$. Sultan II. Osman'ın vefatında yeniçeri askerlerini suçlayan Erzurum Beylerbeyi Abaza Mehmed Paşa, harekete geçerek önce Sivas'ı ele geçirmiş, sonra büyük bir asker grubuyla Ankara şehrini kuşatmıştır. Abaza Mehmed Paşa şehri kuşatarak, kısa sürede kaleye ulaşması endişeleri arttırmıştır. Bu sırada kaleyi kahramanca savunan kişilerin, kuşatma sona erdikten sonra gayretlerinden dolayı ödüllendirilmeleri tehlikenin büyüklüğüne işarettir. Kalenin savunması sırasında dervişleriyle birlikte büyük gayret gösteren ilmiye sınıfından Seyyid Ahmed, Ankara Damga Mukataası'ndan verilen günlük on akçe tahsisatla taltif edilmiştir (AŞS. 21/707:1446 ve 1449). Eşkıya gruplarına karşı şehrin savunulmasında halkla birlikte ulema sınıfının ziyade hizmet eylediği sicillerde açıç̧a belirtilmiştir (AŞS.21/707:1453- 1485 ve 1515).

Abaza Mehmed Paşa ve askerlerinin şehirde oluşturduğu karışıklık, halkın karşı karşıya kaldığı tehlikeyi gözler önüne sermektedir. Eşkıyanın kaleyi kuşattığı sırada hemen yanı başında bulunan çarşılar da bundan etkilenmiştir. Olaylar Ankara Çarşısı'ndaki en büyük vakıf külliyesi olan Mahmud Paşa'nın mülklerine gelip dayanmıştır. Sicil kaydında vakıf mülklerinin; harab olup mahlûl olmağla 1036 tarihiyle müverrih tecdîd-i icâre-i muaccele ile muâmele olunmak için temessük verildiği belirtilmiştir (AŞS. 29/715: 453). Eşkıya tahribinin şehirdeki vakıflar üzerinde farklı örnekleri vardır. Örneğin, Abaza Mehmed Paşa'nın askerleri 21 Receb 1033/9 Mayıs 1624 tarihinde Nalbantoğlu Muallimhanesi Vakfı'nın Eskiciler Çarşısı'nda bulunan dükkânını da

\footnotetext{
9 İcâreteyn, çift kira anlamına gelmektedir. Muhtemelen XVI. yüzyıldan itibaren uygulanan bu kira sistemine göre, ancak işletilemeyecek bir hale düşmüş vakıf emlakin tekrar kiralanmasında uygulanmıştır. Bazı vakıfların gelir kaynağını teşkil eden gayrimenkuller bazen öyle harap bir hale geliyordu ki gelirleri, vakıf emlakin gerekli bakım ve onarımına kâfi gelmiyordu. Bu yüzden XVIII. yüzyılda vakıf gayrimenkullerinin işletilmesinde en çok kullanılan kiralama usulüdür (Yediyıldız, 2003: 136).

10 ... Yorgancılar Çarşısında vakî̀ bir tarafı merhûm Mahmud Paşa Evkâfi'na ve ardı viraneye ve tarafeyn-i taraf-ı tarîk-i âmme müntehi olub iki bab dükkan Celâlî istilasında ihrak oldukda tamirine vakfin müsâadesi olmamak ile yiğirmi seneden ziyâde hâlî ve muattal" olduğu belirtilmiştir (AŞS. 21/707: 224).

${ }^{11}$ Abaza Mehmed Paşa, 1621 yılında Sultan II. Osman'ın öldürülmesinde Yeniçeri askerlerini sorumlu tutmuştur. Yeniçerilerin, padişahın katlinde parmağı olduğunu düşünen Erzurum Beylerbeyi Abaza Mehmed Paşa, bu grubun üstesinden gelmek için çevresine topladığı sekbanlarla Erzurum'da Yeniçerileri imha etmeye kalkışmıştır. Yeniçeriler arasında huzursuzluk başlayınca, Abaza durumdan istifade ederek bir yandan sancaklara kendi adamlarını görevlendirmiş, diğer yandan da halktan vergi toplamaya başlamıştır. Kendisine katılımlarla yaklaşık otuz bin askere ulaşan Abaza Mehmed Paşa, Sivas'ı ele geçirerek Ankara üzerine yürümüş ve şehri kuşatmıştır. Abaza Mehmed Paşa, IV. Murad'ın padişah olmasıyla Kayseri yakınlarında Osmanlı ordusuna yenilmiştir. Daha sonra af dileyen Abaza Mehmed Paşa, padişah tarafından affedilerek Erzurum Beylerbeyliği görevini sürdürmüştür. Bk. Mücteba İlgürel, "Abaza Mehmed Paşa", DİA. I, İstanbul, 1988, 11-12.
} 
yakmıştır. O dönemde vakfın kendi dükkânını tamir etmeye gücü olmadığından; Mehmed ve Himmet isimli kiracılara arsa üzerine yapacakları dükkân kendi mülkleri olmak kaydıyla kiraya verilmiştir (AŞS. 21/707: 371). XVII. yüzyılın ilk yarısında Abaza Mehmed Paşa'nın askerlerinin tahrip ettiği bir diğer vakıf gayri menkûlü ise Eskiciler Çarşısı'ndaki musluk vakfına ait dükkândır. Vakıf dükkânı, yakınında bulunan Mahmud Paşa Vakfı'na ait dükkânlarından daha küçük olmasına rağmen, söz konusu vakfın malî zayıflığı yüzünden ancak, Şaban 1033/Mayıs-Haziran 1624 tarihinde tamir edilerek kiraya verilebilmiştir (AŞS. 21/707: 382).

Abaza Mehmed Paşa ve adamlarının Ankara Çarşısı'na verdiği zarar bunlarla sınırlı değildir. Bu dönemde Merhum Hemhüm Vakfı'nın mütevellisi Memi Çelebi b. Ali, mahkemeye gelerek Abaza Mehmed Paşa'nın askerlerinin vakıf dükkânlarını yaktığını belirtmiştir. Vakfın, Celâlî etkisini üzerinden atabilmesi için vakıf mütevellisinin, Ankara kadısına giderek dükkânları tamire güçlerinin olmadığını belirtmesi gerekmiştir. Nihayet şehir kadısı huzurunda mütevelli Memi Çelebi b. Ali, vakıf dükkânlarını Ahmed ve Seydi Ali isimli kişilere 30 yılllı̆ına icâre-i tavile ${ }^{12}$ ile kiraya verilmiştir (AŞS. 21/707: 384).

Ankara Çarşısı'nın Yukarı Yüz kesiminde tahrip edilen yapılardan bir diğeri ise, XV. yüzyılda Anadolu Beylerbeyi olarak görev yapmış olan İshak Paşa Vakfı'nın yapılarıdır. Ankara'da İshak Paşa Vakfı'nın Tahtakale Hamamı yakınında bulunan iki adet dükkânı, Abaza Mehmed Paşa'nın askerleri tarafından yakılmıştır. Dükkânların tamirine vakfın imkanı olmadığından -diğer vakıfların yaptığı gibi- bu vakıfta da icâreteyn uygulaması devreye sokulmuştur. Buna göre 100 akçe icâre-i muaccele ve senede 30'ar akçe icâre-i müeccele karşılığında vakıf dükkânları İbrahim Ağa b. Halil'in oğlu Hamza'ya kiraya verilmiştir (AŞS. 22/708: 168).

Öte yandan Abaza Mehmed Paşa isyanına destek veren Celâlîler, vakıf mülklerini yakıp yıktıkları gibi, vakıfların nakit paralarına da saldırmışlardır. Evâhir-i Cemâziye'lâhir 1035/Şubat-Mart 1626 tarihinde Hammamî el-Hâc Ahmed'in Ankara'da yaptırdığ 1 cami vakfına ait asl-1 mâldan ${ }^{13}$ olan 60.000 akçenin bir kısmı gasp edilmiştir (AŞS. 22/708: 283). Uluçay’a göre bu dönemde belirsizliğin fazla olmasının bir diğer sebebi ise; pek çok kişinin gasp yapmak için karışıklığı fırsat bilerek yağmaya girişmesidir (Uluçay, 1944: 75).

Abaza Mehmed Paşa isyanında vakıf dükkânları ve hanların yanı sıra, şehirdeki çok sayıda özel mülk de zarar görmüştür ${ }^{14}$. Ticarî mekânlar içerisinde halkın yoğun olarak kullandığı alanlar eşkıya tarafından tahrip edilmiştir. Bunların dışından çarşı merkezine bitişik vaziyette bulunan konut alanları da Celâlîler tarafından yakılmıştır. Nitekim Zal Paşa Vakfı'na ait ev yakıldıktan ancak, 29 Cemâziye'l-âhîr 1035/28 Mart 1626 tarihinde Pavlo v. Yasef isimli zımmîye 200 akçe icâre-i muaccele ve senede 120 akçe icâre-i

\footnotetext{
12 Uzun süreli olarak yapıları kiralama şeklidir. Bir maslahata veya vâkıfın şartına dayanmadıkça vakıf akarı bir seneden, vakıf arazisi de üç seneden fazla müddetle kiraya verilemezdi. İcâre-i vâhideli bir vakıf akarın muayyen sebeplerden biriyle üç seneden fazla müddetle veya daimi olarak icârından ibarettir (Ünal, 2011:339)

${ }^{13}$ Vakfın ana parası, sermayesi demektir.

${ }^{14}$ Ankaralı Ali b. Mehmed, Abaza Mehmed Paşa'nın askerlerinin bütün mal ve erzağını yağmaladığını ifade etmiştir (AŞS. 21/707: 377). 13 Şaban 1032/12 Haziran 1623 tarihinde ise Musa b. Mehmed mahkemeye gelerek özel mülkü olan dükkânın Celâlîler tarafından yakıldığını belirtmiştir (AŞS. 21/707: 153).
} 
müeccele $^{15}$ ile kiraya verilebilmiştir (AŞS. 22/708: 205). Aynı şekilde, Karaca Paşa Vakfı'nın cami kapısı aydınlatması ve çeşmesinin bakımı için tahsis edilen dükkânın eşkıya tarafından yıkılmasından sonra vakıf mütevellisi üç sene sonra mahkemeye gidebilmiştir. O yıllarda vakıfların gelir-gider bütçeleri çoğu zaman ucu ucuna denkleştirildiği için vakıfların yıkımların ardından kısa sürede toparlanması mümkün olamamıştır (AŞS. 23/709: 267).

Celâlî isyanı sırasında askerîler ${ }^{16}$, şehir ileri gelenleri, din adamlar $1^{17}$ ve halk işbirliği içinde hareket etmiş olmasına rağmen, olaylar kısa sürede önlenememiştir. Şehirde; "nice def'a men' ettiğinden" eşkıyalık olayları bitmesi gerekirken, bir süre sonra tekrar ortaya çıkmıştır. Celâlî eşkıyalığının farklı zamanlarda şehrin farklı bölgelerinde ortaya çıkması, olayların tam olarak bitirilemediğini göstermektedir. Olayların ortaya çıktığı ilk zamanlarda şehrin yukarı yüz olarak ifade edilen kısmı olaylardan etkilenmişken, daha sonraki süreçte şehrin dışında bulunan yapılar da eşkıya tarafından tahrip edilmeye başlanmıştır. Nitekim Evâil-i Cemâziye'l-evvel 1036/Ocak-Şubat 1627 tarihinde Ankara şehrinde yaş sebze ve meyvenin satıldığı Kapan Hanı eşkıya tarafından yakılmıştır. İsa Bey Fenârî Vakfı'na ait olan Kapan Hanı yakılınca, uzun süre tamir edilmeyi beklemiştir (AŞS. 23/709: 855).

Celâlî eşkıyası şehir dışında bulunan Doğanoğlu Mahmud Bey Zaviyesi'ni de tahrip etmiştir. Zaviye binası eşkıya tarafından büyük oranda tahrip edilmiş ve bu durum, 23 Cemâziye'l-âhir 1035/22 Mart 1626 tarihinde kayda geçirilmiştir (AŞS.22/708:178). Benzer şekilde, Celâlîlerin baskınlarından Hemhüm Vakfı'nın aldığı zarar, daha büyüktür. Vakıf mütevellisi Memi Çelebi, Bazar-i Ganem Çarşısı'nda bulunan dükkânların eşkıya tarafından yakıldığını ifade ederek, buradaki dükkanların ancak icâreteyn usûlü ile tamir edilebileceğini kadı huzurunda ifade etmiştir (AŞS.23/709: 26).

Yüzyılın ortalarına doğru sipahilerin destek verdiği Celâlîler, Ankara'da sof ticaretinin yapıldığı mekânları doğrudan hedef almaya başlamıştır. Evâhir-i Zilhicce 1036/Ağustos-Eylül 1627 tarihinde gönderilen bir hükümde, eşkıyanın yaptığ1 yıkımın ardından daha büyük toplumsal sorunların ortaya çıktığı anlaşılmaktadır. Buna göre; Mahmud Paşa-yı Velî Vakfı dükkânlarına bazı kimesneler icâre-i muaccele ve icâre-i müeccele ile tasarruf iken eşkıya istilasında dükkânlar bi'l-külliye harab olup binalardan kat'ân eser kalmayub, hâlî ve muattal kaldıkdan sonra arâzi-i mezbûreyi mütevellî-i vakf zabt ve mâl-ı vakf ile ma'mûr ve abâdân etmek icâb iderken arâzi-i mezbûrun üzerinde izn-i mütevellî olmadan fuzûlen bina ilhâk edilmiştir (AŞS. 23/709: 746). Anlaşıldığı kadarıyla; Celâlî olayları sırasında yaşanan siyasî belirsizlik nedeniyle Mahmud Paşa Vakfı'na ait çarşıların yerine mütevellînin izni olmadan bina yapmak isteyen firsatçılar ortaya çıkmıştır.

\footnotetext{
15 İcâre-i müeccele tecil edilmiş, ertelenmiş kira demektir. Aslında normal bir kira bedelinden çok düşük olan icâre-i müecceleyi değiştirmek de mümkün değildir (Yediyıldız, 2003: 136).

${ }^{16}$ Celâlîlere karşı verilen başarı mücadele kimi zaman askerî manada terfileri beraberinde getirmiştir. Küçük Haymana Voyvodası Devran Ağa, eşkıyaya karşı gösterdiği başarılı koruma sayesinde sancak beyliğine tayin edilmiştir. Bk. Ö. Ergenç, XVI. Yüzyılda Ankara ve Konya, s. 67.

${ }_{17}$ Ankara şehrinin Celâlîlerden korunmasında şehir kadısının büyük bir rolü vardır. 1603 yılında Ankara'y1 Küçük Hüseyin isimli eşkıya kuşattığında, şehirde köşebendler ve metrisler yapıp koruyan şehir kadısı olmuştur. Yine Celâlî Hasan'ın şehri 80.000 kuruş haraca bağladığında bu sorunun çözülmesinde şehir kadısı yine ön plandadır. Bk. Ö. Ergenç, XVI. Yüzyılda Ankara ve Konya, s. 87.
} 
Mahmud Paşa Vakfı'nın binaları ile ilgili; Evâhir-i Rabî' ü'l-evvel 1037/Kasım-Aralık 1627 tarihli belgede; H.1022/M.1613 tarihinde sof ticaretinin merkezi olan dükkanların yandığı, aynı dükkanların H.1036/M.1626 tarihinde ise Celâlîler tarafından yeniden ateşe verildiği ifade edilmiştir. Bu sırada vakfın, At Pazarı'na açılan kısmındaki; Sûk-ı Sipâh, Sûk-1 Kaftancıyân ve Sûk-1 Yahudiyân çarşılarında bulunan dükkânlarının tamamı yıkılmıştır. At Pazarı tarafındaki dükkânların bir kısmı, 240 akçe icâre-i muaccele ve 20 akçe icâre-i müeccele ile kiraya verilebilmiştir (AŞS. 29/715: 453). Osmanlı'da ehl-i örf yani askerî sınıfa mensup kişilerin karıştığı eşkıyalık hareketlerinde Ankara şehrinin ticarî mekânları hedef alınarak ticaret kısıtlanmıştır. 17 Rebîül-evvel 1047/9 Ağustos 1637 tarihinde şehir halkı, henüz daha Celâlî olaylarının etkisini üzerinden atamamıştır ${ }^{18}$.

XVII. yüzyılın ikinci yarısında Ankara şehrinde görülen Celâlî olayları biraz daha azalmıştır ${ }^{19}$. Nitekim bu tarihlerde Celâlîlerle ilgili bulabildiğimiz tek kayıt Evâhir-i Zilka'de 1076/Mayıs-Haziran 1666 tarihlidir. Askerî sınıfa mensup kişilerin çıkardığı veya destek verdiği Celâlî olayları, XVII. yüzyılın ikinci yarısında azalarak devam etmiştir. Evâhir-i Zilka'de 1076/Mayıs-Haziran 1666 tarihinde Ankara Çarşı'sında Mahmud Paşa Vakfı'na ait 100 dükkânlı bedestenin tahrip edilerek mallarının yağmalanması, eşkıyalığın az da olsa varlığına işarettir. Olaylar sırasında aynı vakfa ait Sûk-1 Takyeciyân gibi, bedestenin batı tarafında bulunan Sûk-1 Kuyumcuyân ve Sûk-1 Kuşakcıyân çarşılarının bu yapıya bitişik vaziyette olmaları nedeniyle tahrip edilmişlerdir. Belgelere göre, XVII. yüzyılın ikinci yarısında şehir merkezinde eşkıya grupları bedesteni mesken tutmuşlardır20.

\section{b-Eşkıyâlık Açısından XVIII. yüzyılda Şehrin Görünümü}

XVII. yüzyılın ikinci yarısında Osmanlı Devleti'nin yaşadığı ağır yenilgiler, ekonomik krizler ve idarî zafiyetlere rağmen, Celâlî olayları yüzyılın ikinci yarısında giderek azalmıştır.

$\mathrm{Bu}$ durumun belki de en önemli sebeplerinden birisi, Osmanlı üretim ilişkileri ve siyaset biçimindeki değişim ile devlet-toplum arasındaki bağlantının yeni forma dönüşmesidir. XVII. yüzyılda adem-i merkezileşme olarak ifade edilen taşradaki yerel unsurların siyasete ve idareye daha fazla entegre olması, toplumsal ve siyasî açıdan rahatlamaya yol açmıştır. Yerli âyanların güç kazanmaları devletin taşrayı daha iyi

\footnotetext{
${ }^{18}$ Belgede; Celâlilik üzere iken katl olunan Abaza Hasan'ın ve yine Celâlîye tabî' olub katl olunanlarm ve firar üzere olanların cümle emvâl ve erzak ve eşyası ve çiftlikler beytü'l-mâle bırakıldığı ifade edilince şehir halkının korku ve endişeleri bir nebze azalmış olmalıdır (AŞS. 45/731: 490).

${ }^{19}$ Daha XVII. yüzyıl başlarından itibaren Celâlı̂ olaylarının azalmaya başladığı Hülya Taş tarafından ifade edilmektedir. Bk. XVII. Yüzyılda Ankara, s. 109.

${ }^{20}$ Belgeye göre; Merhûm Mahmud Paşa'nın vilâyet-i Anadolu'da nefs-î Ankara'da vakî̀ mezbûrun Bezzazistanı olub 15 seneden berü mütecâviz olub vakfa kadr olduğu arz olundukta bedestene tasallut olan eşkıyaları bedestenden def' etmek babında hattı hümâyun sadır olmuştur (AŞS. 56/742: 947). Vakıfla ilgili 23 Zilka'de 1084/1 Mart 1674 tarihli fermanda ise, vakıf bedestenin eskisi gibi vakıf tarafından kiraya verilerek işletilmesi hususu ifade edilmiştir.
} 
kontrol altına almasına, halkla ilişkilerinde daha fazla âyanlara dayanmasına olanak sağlamıştır (Quataert, 2005: 159).

XVIII. yüzyılda Osmanlı Devleti'nde güçlü yerel hanedanların ortaya çıkması, devlet-toplum ilişkilerini değiştirmemiştir. Bu süreçte devlet malî ve idarî yetkileri dağıtarak taşrada devlete olan bağllığı güçlendirmiştir. Taşradaki yeni güç ilişkileri, bir yandan toplum içinde servet sahibi olmayı, diğer yandan da merkezî iktidara yakın olmayı zorunlu kılmıştır. Yerel hanedanlar ve âyanlar elde ettikleri idarî ve malî gücü devam ettirebilmek için devletle uzlaşmaya ve taşradaki dengeleri sürdürmeyi politika haline getirmişlerdir. Taşrada âyanların güçlerini ve saygınlıklarını belirleyen en önemli faktör, savaş zamanlarında devletin asker taleplerini karşılamalarıdır. Bu yüzden her âyan ailesi aynı zamanda çevresinde kalabalık bir grup bulundurmak zorunda kalmıştır. Askerî gücün hem devlet katında hem de toplum nezdinde itibar gördüğünün farkında olan âyanlar, kazandıkları itibarla etraflarını denetlemeye başlamışlardır.

Kazalarda bulunan resmi âyanlar merkezî idarenin asker işlerini görürken diğer taraftan da devletin vergilerinin toplanmasına yardımcı olmuşlardır. Âyanların devlet adına haktan vergi toplaması en fazla suistimal edilen, yolsuzluk yapılan kısımdır. Halka vergi yükleyen âyanlar, kendileri için de ücret koymak suretiyle devletin istediği vergileri, birkaç kat daha fazla toplamak suretiyle bunları devlet görevlileri ve kendi adamlarıyla paylaşmışlardır. Âyanların defterlerden yazan miktardan daha fazla vergiyi halktan talep etmesi, sürekli yeni şikayetlere konu edilmiştir (Özkaya, 2014: 254). Âyanlar hakkında yapılan şikayetlerin çoğunu fazla vergi toplama meseleleri oluşturduğu; Ahi Şerafeddin Vakfı mütevellisi Seyyid Hafız Mehmed'in şikayetinden anlaşılmaktadır ${ }^{21}$. XVIII. yüzyılın ikinci yarısında âyanlar, şehir ileri gelenlerinin veya halkın istediği kişilerden olmaktan çok, zorbalardan seçilmeye başlayınca devlet işleri de gereği gibi yürümez duruma gelmiştir. Kimi zaman şehirdeki kadı, naib, vali, müftülerin âyanlarla birlikte hareket ettikleri düşünüldügünde halk üzerindeki baskıları da artmıştır (Özkaya, 2014: 213).

Âyanların devlet ile yaşadıkları idarî ve malî sorunlara rağmen, onların kendi bölgelerinde yerel bir idareci oldukları ve oralarda kendi otoritelerini sürdürdükleri görülmektedir. Güçlü yerel otoritenin âyanlar tarafından tesis edilmesi hem şehirlerde hem de kırsal bölgelerde kontrolü ele geçirmeleri eşkıyanın konumunu da etkilemiştir. XVIII. yüzyılda âyanların güçlenerek şehirlerde yerel otoriteler haline gelmesi, eşkıyanın eskiden olduğu gibi merkezî hükümet ve yerel hanedanlarla ya çatışma yada uzlaşma yolundan birini tercihe zorlamıştır (Ertaş, 2009: 150).

Öte yandan âyanların yerel otorite olmalarının yanında, XVII. yüzyılın ikinci yarısından itibaren gelişen yeni şartlara bağlı olarak, merkezden atanan idarecilere göre yerli idareciler, daha avantajlı duruma gelmişlerdir. Bu durum taşradaki eşkıyalığı da doğrudan etkilemiştir. Eski dönemlerde merkezden atanan idarecilerin görev bölgelerini tanımamaları, eşkıya için bir avantaj oluştururken, yeni dönemde bölge halkıyla yakın bağları olan âyanlar karşısında eşkıyanın barınma imkanını azaltıştır. Eşkıyalar bu sebeple merkezî iktidarı zor durumda bırakacak büyük olaylara girişemedikleri

${ }^{21}$ Vakıf mütevellisi vakfiyede belirtilen altı köyün resmi öşür, cürm-ü cinâyet ve diğer vergilerinin kanunsuz olarak âyanlar tarafından alındığını ifade etmiştir(AŞS. 207/893:211). 
müddetçe bir şekilde yerel otorite ile anlaşma yolunu seçmek zorunda kalmışlardır (Ertaş, 2009: 151). Bu yüzden olsa gerek; XVIII. yüzyılda eşkıyalığın şekli değişmeye başlamıştır.

Âyanların güçlenmesi zaman içerisinde onların isimlerinin eşkıya grupları ile zikredilmesini beraberinde getirmiştir. Bu gruplar arasında oluşturulan işbirliği celâlî döneminden farklı bir eşkıyalık anlayışını geliştirecektir. Âyanların bazı durumlarda eşkıyaları kullanarak çıkar temin etmeleri, varlıklarını sürdürebilmek adına onları zararlı faaliyetlere yönlendirmiştir. Dolayısıyla XVIII. yüzyılda kimi zaman zûlüm ve zorbalıkları âyanlar yapıp faaliyetleri devlet güçleri tarafından engellenmeye çalışılırken"22, kimi zaman da âyanların bizzat devlete destek oldukları, kendi bölgelerindeki eşkıya gruplarının ortadan kaldırılması için gerekli çabayı gösterdikleri gözlerden kaçmamaktadır.

Halktan zorla vergi toplayan, yağma yapan ve böylece halkın şikâyet etmesine neden olan âyanlar ve mütegallibeler, XVIII. yüzyılda özellikle askerî ve ekonomik nedenlerle devlette görülen otoritesizlik ve zaaflardan faydalanarak belirgin duruma gelerek, kanunsuz yollara sapmışlardır (Kaya, 2013: 59). Zamanla âyanlar gibi voyvodalar ve çıkar temin etmek isteyen diğer devlet memurları da mücadelelerini eşkıya gruplarına dayandırmayı başarmışlardır. Ankaralı âyan ailesinden olan Muslupaşazâde ailesi böyle bir uygulama ile şehirde gücünü ispat etmeye çalışmıştır ${ }^{23}$ (AŞS. 123/809: 252). XVIII. yüzyılda Muslupaşazâde Salih Bey'in oğullarından Mehmed Bey, Niğde Livası mutasarrıflı̆̆ı iken, kardeşi Osman Bey ise Ankara'da âyanlık mücadelesi ile ön plana çıkmıştır. Ankara'da Muslupaşazâde Salih Bey ve çocukları eşkıyalık faaliyetlerinde bulunarak, âyanlıklarını ispat etmeye çalışmışlardır24(AŞS. 123/809: 144). Diğer taraftan Mimarzâde ailesinin durumu da Muslupaşazâde ailesinden farklı değildir. Mimarzâde Mehmed Şakir Efendi'nin halk üzerinde etki ve gücünü gösterebilmek adına eşkıya grupları ile beraber olup, halkı sindirmeye çalışması merkezî yönetimle arasını açmıştır (AŞS. 159/845:95). Mimarzâde Mehmed Şakir Efendi'nin çocukları da Ankara ahalisine ve bölge vakıflarına bir takım zorluklar çıkarmıştır. Sicillere göre Mimarzâde Mehmed Şakir Efendi'nin vefatından sonra çocukları Abdullah, Salim, Arif ve Ali Efendiler; Ankara'da Hıdırlık ve Baba Çeşnigir Vakıflarının arazilerini babamızdan intikal etti diyerek zorla zapt etmişlerdir.

\footnotetext{
22Örneğin Maraş beylerbeyi Rişvanzâde Süleyman Bey'in ölümü üzerine şehirde nizama uymayan işler görülmeye başlanmıştır. 1764 yılında Rişvanzâde Süleyman Bey'in vefatı ve Mütesellim Bayezidzâde Numan Bey'in Maraş'ta olmadığı bir zamanda Zülkadiroğlu Süleyman Bey, askerleriyle Maraş beylerbeyinin sarayına girerek hem Numan Bey'e hem de Rişvanzâde Süleyman Bey'e ait mal, eşya ve parayı yağmalamıştır (Söylemez, 2007: 75).

23 Âyanların eşkıyalıkla ilgili tavırları Anadolu'da ve Rumeli'de birbirinden farklılık göstermektedir. Örneğin XVIII. yüzyıl sonlarına doğru dağlı eşkıyalığı gelişmeye başlamıştır. Rumeli'de daha yaygın olan dağlı eşkıyalığını âyanlar himaye etmişlerdir. Rumeli'deki dağlı eşkıyalığı yüzünden halk yerini yurdunu terk ederek göç etmiştir. Sultan II. Mahmud'un merkezî otoriteyi güçlendirmeye başlamasıyla Rumeli'de yaygın olan dağlı eşkıyalığı zamanla azalmıştır. Bk. M. İlgürel, “Osmanlılarda Eşkıya”, DİA. XI, İstanbul, 468.

${ }^{24}$ Halktan zorla vergi toplayan, vergi vermeye yanaşmayanları cezalandıran Muslupaşazâde Salih Bey'in faaliyetleri şikayetlere konu edilmiş ve akabinden Murtazaâbad Nahiyesi'ne bağlı Mirgazi Köyü'ndeki Salih Bey'in bütün mallarının müsadere edilerek idamına karar verilmiştir (AŞS. 134/820: 389).
} 
Vakıfların gelirlerine el koyan, kurumları iş göremez duruma getiren bu ayan ailesinin durumu İstanbul'a şikayet edilmiştir (AŞS.186/872: 175).

Âyanlığının yanında, şehirde mütesellimlik görevini de sürdüren Müderriszâde Ahmed Efendi'nin şehir halkına yaptığı zulüm ve vergi toplarken devlete verdiği zarar, onun kısa süre sonra Bursa'ya sürgüne gönderilmesine yol açmıştır ${ }^{25}$ (AŞS.190/876:239). Müderriszâde Ahmed Efendi'nin sürgüne gönderilmesinden sonra boşluğu, Nakkaşzâde es-seyyid Ali Ağa doldurmuştur. Nakkaşzâde es-seyyid Ali Ăga kendisinden önce âyanlık iddiasında bulunanların başlarına gelen olayları bildiği için Ankara civarında eşkıyalık yapan levendlerle işbirliğine girişmemiş tam aksine, onları yakalatarak şehir kadısına teslim etmiştir ${ }^{26}$ (AŞS.196/882:152).

XVIII. yüzyılda Ankara'da âyanlık yapan ailelerin faaliyetleri sosyolojik olarak farklı yönlerden ele alınmalıdır. Şimdiye kadar âyan denince halka eziyet ederek onlardan zorla vergi toplayan, eşkıya grupları ile işbirliği yapan aileler akla gelmiştir. Oysa âyan ailelerinin ömrü hayatları sadece zorbalık, eşkıyalık gibi kötü işlerle sona ermemiştir. Âyan aileleri hakkında oluşan olumsuz imaja rağmen, onların iyi işler yaptığını gösteren bir takım güzel hasletleri de vardır. Âyan aileleri içinde yaşadıkları toplum için faydalı yatırımlar yaparak hayırseverliklerini göstermişlerdir. Bu manada Ankara'da âyanlık iddiasında bulunan ve reayaya eziyet etmesi sonucunda sürgüne gönderilen Müderriszâde ${ }^{27}$ ailesi, Ankara'daki cami ve medreseleri desteklemişlerdir. Yine Nakkaşzâde ${ }^{28}$ ailesinin uygulamaları da bundan farklı değildir. Aile mensuplarından Ali oğlu Seyyid İbrahim, Odabaşı Köyü'ne cami yaptırmıştır. Âyan aileleri içinde Mimarzâde ailesi oldukça ilginçtir. Bulundukları bölgede bir takım vakıf mülklerini gasp ederek, gelirlerini toplamak suretiyle onları iş göremez duruma getiren Mimarzâde es-seyyid Mehmed Şakir Efendi'nin ${ }^{29}$ hayatının sonlarına doğru Arasta Mescidi ve Medresesi dışında Erzurum Mahallesi'ndeki camiye yaptığ

\footnotetext{
${ }^{25}$ XIX. yüzyıl ilk yarısında Mimarzâde Abdullah Efendi sof tüccarlarına zorluk çıkarmış, Ankara Damga Mukatası'na gitmesi gereken vergileri gasp etmiştir. Mimarzâde Abdullah Efendi hakkında sof tüccarların yaptığ1 şikayetler üzerine Kütahya Kalesi'ne hapsedilmesi emredilmiştir (AŞS.190/876: 326).

${ }^{26}$ Şehir yöneticileri Ankara'da eşkıyalığın önlenmesi için cami imamları ile birlikte çalışmışlardır. İmamlar bulundukları köylerde halkın temsilcileri olmuşlardır. Bu yüzden imamlar, devletin düzeninin devamı için gelen emirlere destek verdikleri gibi eşkıyaya karşı halkın desteğini de talep etmişlerdir. Bu devirde imamların sadece eşkıyaya karşı devlete sözlü destek vermeleri yeterli değildir; aynı zamanda imamlar, devletin eşkıya takibi için gönderdiği paşalara aynî ve nakdî yardımlarda bulunmuşlardır (AŞS. 72/758: 115).

${ }^{27}$ Ankara'da Müderriszâde ailesinden bazı kişiler çeşitli vakıflarda görev yapmışlardır. Şefik Efendi, Debbağhane Camii'nde kürsü şeyhliğini yapmaktadır (AŞS.381/1067:62). Aile mensuplarının Ankara'da hem Kamerüddin Medresesi'ne hem de Zeynel Âbidin Efendi Cami ve Medresesi'ni destekledikleri Vakıflar Genel Müdürlüğü'ndeki kayıtlardan anlaşılmaktadır (VGM. Deft. 384/134 - 372/109 ve 2624/35).

${ }^{28}$ Nakkaşzâde Ali oğlu Seyyid İbrahim'in Odabaşı Köyü Camii'ni yaptırdığı bilinmektedir (AŞS. 179/865:182 ve BOA. EV. MKT. CHT.189/63)

${ }^{29}$ Ankara'da Mimarzâde Hanı'nı yaptırmışlardır (AŞS. 187/873: 122). Ankara Çarşısı'nda Mimarzâde esseyyid Mehmed Şakir Efendi Vakfı'na bağlı Arasta Mescidi vardır (AŞS.240/926:123). Aynı vakfın İmaret Mahallesi'nde Medresesi de bulunmaktadır.(AŞS. 300/986:429). Medreseden başka Mimarzâde es-seyyid Mehmed Şakir Efendi Vakfı, Erzurum Mahallesi Camii'nin 5 akçeye vaizini maaşa bağlamıştır (AŞS. 317/1003:186). Vakfın çeşmesinin de olduğu bilinmektedir.
} 
isminden bahsettirmiştir (AŞS. 219/905:99). Benzer şekilde Muslupaşazâde ${ }^{30}$ ailesi mensupları da şehirdeki dini yapıları desteklemişlerdir.

XVIII. yüzyılda şehir merkezlerinde yöneticilerin sağladığı otorite nedeniyle eşkıyalık hareketleri yön değiştirmeye başlamıştır. Şehirlerde eşkıyalığın azalmasında âyanların kurduğu otoritenin önemli etkisi vardır. Bu yüzden olsa gerek âyanlık devrinde eşkıyalık kırsal bölgelerde görülmeye başlanmıştır. Ankara'da eşkıyalık özellikle iki noktada yoğunlaşmıştır. Bunlardan birincisi; Ankara şehrinin doğusunda yaşayan Yörük, Türkmen ve Ekrad aşiretlerin yaşadıkları bölgelerdir. Vadi ve dağlık bölgelerde yaşayan bu gruplar, bölgeden geçen tüccarların yollarını keserek eşkıyalık yapmışlardır ${ }^{31}$. Bu yüzden bölgede yaşayan aşiret reisleri sık sık ikaz edilmişlerdir (AŞS. 72/758: 419). Örneğin Türkmenler arasında eşkıyalık, XVII. yüzyılın ikinci yarısında artmıştır. Osmanlı Devleti'nin bu zamanda karşılaştı̆̆ı siyasî, iktisadî ve askerî sorunlar toplumun her kesimini etkilediği gibi, kırsalda yaşayan grupları da etkilemiştir.

İktisadî açıdan şehir merkezinden uzakta kırsal alanlarda görülen eşkıyalık; ticaret, tarım ve hayvancılıkta etkisini göstermiştir. Boş kalan araziler hububat fiyatlarının arttırmış, çevre şehirlerden mal akışı düzenli yapılamamış, eşkıya korkusuyla sürüler geniş alanlarda otlatılamamış olması sıkıntıları arttırmıştır. Devletin sosyal düzeninde yaşanan bu bozulma, fırsatçı grupları farklı kazanç yollarına yöneltmiştir. Bu açıdan bakıldığında bir taraftan sosyal gelişmelerden etkilendiği için eşkıyalık olaylarına katılanlar, diğer taraftan eşkıya gruplarının sözlerine inanarak bunlara katılanlar vardır. Örneğin, XVIII. yüzyılın ilk yarısında Tabanlı Türkmenleri Ankara Sancağı'nın hemen her bölgesinde eşkıyalık yapmaya başlamıştır ${ }^{32}$.

İster Türkmen isterse Kürd veya Yörük aşiretlerinden olsun, tüccarların yolunu kesen grupların kısa sürede varlıklı kişiler haline geldikleri görülmüştür. Eşkıya grupları bu dönemde Ankara civarındaki stratejik geçit noktalarında konumlanmışlardır. Bunlardan biri Hamamlı Boğazı diğeri de Karayokuş Geçidi' dir. XVIII. yüzyılda Ankara Sancağı sınırları dâhilinde yol eşkıyalığının yoğun olarak görüldüğü Beybazarı-Bolu arasında bulunan Hamamlı Geçidi; Beypazarı'na iki, Ankara'ya onbeş saat uzaklıktadır. Örneğin 17 Cemâziye'l-evvel 1090/726 Haziran 1679 tarihinde Edirne'li Ali b. Hüseyin ve Ali b. Mehmed'in yolunu kesen, 60 kişilik yol eşkıyası, kısa süre içerisinde tüccarların mallarını gasp etmişlerdir. Bu dönemde eşkıyayı takip için gönderilen müfettiş Hüseyin Paşa tüccarların şikayetlerini dinleyerek bu olayları engellemeye çalışmıştır (AŞS. 60/746: 151). Ancak Türkmenlerin katıldığ1 yol eşkıyalığı

\footnotetext{
${ }^{30}$ Bazar-1 Ganem Çarşısında Muslupaşazâde Hanı yapılmıştır(AŞS. 192/878: 249). Hanın etrafında bulunan üç dükkan Taceddin ve hayali Ahmed Paşa camilerinde Kur'ân- Kerim okumaları için vakfedilmiştir. Daha sonra burada Sun'iyye Medresesi kurulmuştur(Özdemir, 1986: 35 ve BOA. EV. MKT. CHT. 22/71). Ayrıca aile mensupları Murtazaâbad Kazası'na bağlı Mirgazi Köyü'nde de cami yaptırmışlardır.

31 Orta Anadolu'da ve diğer bölgelerde yol eşkıyalığı büyük oranda artmıştır. 1737 yılında Rişvanlı Aşireti'ne mensup eşkıyanın Türkmen cemaatinden 350 koyun ve 500 kuruş değerinde peynir ve yün gasp etmesi, devletin bir süre sonra bu cemaatle ilgili politika değişikliğine gitmesine nende olacaktır. Bk. F. Söylemez, "XVIII. yüzyıl Başlarından XIX. Yüzyıl Ortalarına Kadar Maraş ve Çevresinde Eşkıyalık Hareketleri", Sosyal Bilimler Enst. Dergisi XXII, s. 70-71.

${ }^{32}$ Evâsıt-1 Şaban 1130/Temmuz 1718 tarihinde Tabanlı Cemaati'nden Şedid oğlu ve kardeşi; Kara Musa ve oğlu; Şeyhlü Cemâati'nden Ali ve Arab Ömer 70-80 kişilik eşkıya grubu ile kendi halinde yaşayan 27 haneyi basmış, 2 kişiyi öldürmüş, 7 kişiyi de kaçırmıştır (AŞS. 93/779:321).
} 
bölgede sona erecek gibi değildir. Evâsıt-1 Cemâziye'l-âhir 1124/Temmuz 1712 tarihinde Hamamlı Boğazı'nı tutan 40 nefer eşkıya, Beypazarı Voyvodası ile altı saat boyunca savaşmıştır (AŞS. 72/758: 498).

XVII. yüzyılda Ankara şehrini yakıp yıkan Celâlî grupları yerine, XVIII. yüzyılda dağlık ve vadilerle çevrili alanları mesken tutan yol eşkıyalığı gelişmeye başlamıştır. Ortaya çıkan bu yol eşkıyalığına en önemli destek yine reayadan gelmiştir. Yüzyıl içerisinde Türkmenler, Yörükler ve Ekrad grupları olarak tasnif edebileceğimiz birbirinden farklı fakat benzer coğrafî alanlarda yaşayan eşkıya grupları daha fazla ön plana çıkmaya başlamıştır. Devlet içerisinde güç gruplarının değişmesi devletin, onlarla ilgili uyguladığı politikalarla yakından ilgilidir. Böylece XVII. yüzyılda askerî sınıftan kişilerin oluşturduğu isyanlar, XVIII. yüzyılda daha çok reaya sınıfına mensup kişilerin eşkıyalık girişimleri ön plana çıkarmıştır (AŞS. 141/827: 197). İfade edilen bu grupların kimi zaman daha fazla vergi vermemek kimi zaman da yerleşik hayata geçmemek için direnerek Anadolu içlerinde dağılması yol eşkıyalığının önemli sebeplerinden birisi olmuştur.

XVIII. yüzyılda eşkıyalık yapan aşiretlerle devletin mücadelesi farklı şekillerde olabilmiştir. Ankara Sancağı'nda yaşayan Bozulus Türkmen grubuna mensup Tabanlu, Kösne, Oğulbeylü, Şeyhlü, Çayan, İleminlü, Karadîn, Süleyman Haclu ve Hamza Hacılu cemaatleri ile topyekün mücadele edebilmek için Osmanlı merkezî yönetimi belirli tarihlerde bunlara, gasp ettikleri mallar nedeniyle yüklü miktarlarda borç çıkarmıştır (AŞS. 72/758:442). Benzer şekilde yol eşkıyalığı haberleri Çukurcak ve Kalecik kazaları arasında bulunan Karayokuş Geçidi'nde sık sık duyulmuştur. ErzurumDiyarbakır-İran yolu üzeride bulunan geçit için devletin kimi zaman özel önlemler alması gerekmiştir (AŞS.25/711: 1169).

XVIII. yüzyılda Ankara'da eşkıyanın takip edilmesi hususunda bir yandan başkentten sık sık uyarılar gönderilirken (AŞS. 79/765:753), diğer yandan da yeniçeri askerlerinin bu gruplarla birlikte hareket etmemesi konusunda emirler ve yasaklar merkezden gönderilmiştir(AŞS. 76/762: 529). Hobsbawm'ın; bütün toplumlar sosyal eşkıyalığı üretme potansiyeline sahiptir. Bu potansiyel coğrafyanın zorluğuyla doğru orantılı, devletin nüfûzu ile ters orantılıdır (Hobsbawm, 1997: 15) şeklindeki ifadesi, XVIII. yüzyılda kırsal alanlarda yaşayan grupların şartlarıyla örtüşmektedir. Ankara havalisinde konargöçer vaziyetteki grupların, dağlık ve kırsal alanlarda hayvan beslemek suretiyle yaşıyor olmaları, bunlar arasında eşkıyalık olaylarının görülmesine neden olmuştur.

Eşkıyalığın, şehir eşkıyalığından çıkarak kırsal bölgelere doğru kayması, yerel eşraf ve âyanların şehir merkezlerinde sağladıkları otorite ile yakından ilgili olmalıdır. Ankara'da XVII. yüzyılda olduğu gibi celâlî eşkıyalığına benzer bir durum söz konusu değildir. Doğal olarak bu gelişmeler, eşkıya gruplarının vakıf kurumlarına doğrudan baskı kurmasını da engellemiştir. Dolayısıyla XVIII. yüzyıl şer'iye sicillerinde eşkıya gruplarından zarar gören vakıf topraklarına veya gayrimenkullerine az rastlanılması bu yüzdendir. Eşkıya gruplarının bu tarihlerde sadece Ankara şehri kırsalından tahsil edilen beytü'l-mâl vergilerini gasp ettikleri kayıtlardan anlaşılmaktadır (AŞS. 80/766: 877 - 909).

XVIII. yüzyılda çok büyük bir harekete dönüşemeyen eşkıyalık, büyük oranda taşradaki idarecilerin kontrolünde varlığını geçitlerde, yol güzergahlarında sürdürebilmiştir. Bu durum eşkıyanın şehir merkezlerinin uzağında denetimini 
mümkün kıldığı gibi taşradaki kanun ve nizamsızlıkların oluşmasına imkan vermemiştir. Şehir yöneticileri olarak âyan ve bölge eşrafının aralarında işbirliği yaparak eşkıya gruplarını engellemeye çalıştıkları muhakkaktır. Buna rağmen olaylar yok değildir. Eşkıya grupları çabuk hareket edebilen, ani baskınlar yapabilen kişilerden oluştuğu için faaliyetleri de genellikle kısa süreli olmuştur. Bu gruplar kimi zaman yaptıkları baskınlar sonrasında dağılarak köylerine gitmiş, kimi zaman da baskınlar sonrası izlerini kaybettirebilmek için Orta Anadolu şehirleri arasında dolaşıp durmuşlardır.

XVIII. yüzyılda eşkıyalık, bir önceki yüzyılda geniş bir alana yayılan sekban ve sarucaların eşkıyalığından; Türkmen, Ekrad ve Yörük aşiretlerinin eşkıyalığı şekline dönüşmüştür. Aynı yüzyılda az sayıdaki âyan ve eşrafın kendi çıkarları için sürdürdükleri rekabet, Sun-Tzu'nun belirttiği gibi; nihayeti itibariyle uzun vadeli mücadelelerin kazananının olmadığını ortaya koymaktadır (Sun-Tzu, 1971: 73).

Sonuç olarak endüstrileşmiş toplumlar öncesinin zor şartları içerisinde, yolculukların ağır yapıldığı dönemlerde, ticari faaliyetlerin yapıldığı yollar, eşkıyaların en gözde faaliyet alanları olmuştur. Modern devletlerin kurulması, bürokrasideki işleyişin hızlanması, daha düzgün ve hızlı ulaşıma imkân tanıyan yolların yapılması eşkıyalara ağır darbe vurulmasında yeterli olmuştur. Ekonomik gelişmeler, etkili haberleşme ve ulaşım ağlarının kurulması ve devletlerin yönetimsel becerilere ulaşması her türlü eşkıyalığın gelişmesine engel oluşturmuştur (Hobsbawm, 1997: 14-15).

\section{Sonuç}

Anadolu'da Celâlî eşkıyalı̆̆ı, XVI. yüzyıl sonlarında başlamış ve XVII. yüzyılın ortalarına kadar azalarak devam etmiştir. Akdeniz coğrafyasında yaygın olan eşkıyalığın en önemli sebepleri; nüfus artışı, tarımsal üretimdeki yetersizlik, ekonomik dengelerdeki değişiklik, uzayan savaşlar ve siyasî çözülmelerdir.

Celâlî olayları sırasında devlet otoritesi zayıfladığından, halkın eşkıya saldırılarına marûz kalmamak için cilâ-yı vatan/terk-i diyar etmesi kaçınılmaz hale gelmiştir. Ankara bölgesinde görülen Celâlî olayları halkın, daha güvenli bölgelere yani kırsaldan şehre doğru gitmesine neden olmuştur. Sultan II. Bayezid'ın vakıf reayasının bir kısmının güvenli olduğu için Ankara şehir merkezine gelmesi bu tezi doğrulamaktadır. Öte yandan vakıf yapıları üzerinde görülen Celâlî tahribatında kır-şehir ayrımı yapmak güçtür. Celâlî eşkıyasının hem kırsaldaki vakıflar üzerinde, hem de şehir merkezlerinde vakıflar üzerinde büyük yıkıma neden olduğu açıktır.

Celâlî olayları sırasında Ankara şehrindeki vakıflar üzerinde büyük bir yıkım söz konusudur. Mahmud Paşa Vakfı'nın Bedesteni dişında, Çorapçılar, Kuşakçılar, Takyeciler, Kuyumcular, Kaftancılar, İplikçiler, Kemeraltı, Sipah ve Yahudiyan olmak üzere dokuz çarşının çeşitli tarihlerde eşkıya tarafından ateşe verildiği görülmektedir. Diğer vakıflarda meydana gelen hadiseleri de göz önünde bulundurursak; Celâlî olayları Ankara şehir hayatına büyük zarar verdiği anlaşılır. Vakıf yapılarının Celâlî olaylarında yıkıldıktan sonra, yeniden inşâ edilmesi 3 ile 15 yıl arasında değişen bir süreyi kapsamıştır. Öte yandan XVII. yüzyılda vakıfların Celâlî tahribatından kendi malî imkanları ile çıkmaları mümkün olmadığından, ancak icâreteyn sistemi sayesinde tekrar toparlanabilmişlerdir. Celâlî eşkıyasının zarar verdiği İshak Paşa, Mahmud Paşa, Yeğen 
Bey, Zal Paşa, Hemhüm ve Nalbandoğlu Vakıfları bu krizden çıkabilmek için icâreteyn usûlü ile taşınmazlarını tamir ve inşâ yoluna gitmişlerdir. $O$ yıllarda Celâlî belirsizliğinin ne zaman biteceği kestirilemediğinden kimi zaman yakılıp yıkılan vakıf binalarının yerine -mütevellinin haberi olmadan- başka kişiler tarafından izinsiz binalar yapılmıştır. Bu durum Celâlî olayları sırasında şehirlerde yaşanan yasa dışılık, keyfîlik ve fırsatçılığı da ortaya koymaktadır.

XVII. yüzyılda askerî sınıf mensuplarının başlattığı veya destek verdiği isyanlardan, XVIII. yüzyılda yol eşkıyalığına doğru kayma söz konusudur. Bunun en önemli sebeplerinden biri; Celâlî olaylarını organize eden kişilerin peşine düşen devletin, onları yakalaması, bir kısmını hapsedip bir kısmını da idam ederek ortadan kaldırmasıdır. Celâlî liderlerinin ortadan kaldırılması, onlara destek veren kişilerin dağılmasına Anadolu'da küçük gruplar halinde eşkıyalık faaliyetlerini sürdürmelerine neden olmuştur. XVIII. yüzyılda eşkıyalık olaylarının azalmasında etkili olan diğer bir husus ise, İstanbul'dan atanan idarecilerin yerine, halkı taniyan, yerel otoritenin(âyan ve eşrafın) güçlenerek eşkıyalığın alanını daraltmasıdır.

XVIII. yüzyılda Ankara'da âyanlık yapan ailelerin faaliyetleri çeşitli açılardan incelenmelidir. Siyasî açıdan âyan ailelerinin eşkıya grupları ile işbirliği içinde bulundukları, halktan daha fazla vergi toplayabilmek için onlara eziyet ettikleri belgelerde sık sık dile getirilmiştir. Oysa halka kötü davranan, onların kazancını gasp eden aynı âyan aileleri vakıf eserleri tesis ederek veya mevcut eserleri destekleyerek hem halkın gönlünü kazanmaya çalışmışlar hem de hayırseverliklerini göstermişlerdir. Bunlardan Mimarzâde, Müderrriszâde, Muslupaşazâde ve Nakkaşzâdeler hayır eserleri yaptırarak varlıklarını halka kabul ettirmişlerdir.

Son olarak daha genel bir tasvir yapmak gerekirse; XVII ve XVIII. yüzyıllardaki eşkıyalık hareketleri arasında bir takım temel farklılıklar vardır. XVII. yüzyıl Celâlî eşkıyalığına katılan kişiler askerî sınıftan oldukları için şehirler üzerinde hakimiyet kurmayı planlamışlardır. Oysa XVIII. yüzyıl eşkıyalığının kaza merkezleri ve kasabalar üzerinde doğrudan etkisi söz konusu değildir. En azından XVIII. yüzyıl şer'iye sicillerinden eşkıya gruplarının şehirlerdeki vakıflar üzerinde -Celâlî döneminde olduğu gibi- açık bir tahribatı söz konusu olmadığı anlaşılabilmektedir. XVIII. yüzyılda Ankara kaza merkezinde âyan ve eşrafın sağladığı otorite, eşkıyalığın merkezden uzakta, kırsal bölgelerde faaliyet göstermesine yol açmıştır. $d$ 


\section{Kaynakça}

Ankara Şer'iye Sicili(AŞS): AŞS.7/693 - AŞS. 8/694 - AŞS. 9/695 - AŞS.10/696 - AŞS. 11/697 - AŞS. 12/698 - AŞS.13/699 - AŞS. 14/700 - AŞS. 15/701 - AŞS. 16/702 - AŞS. 17/703 AŞS. 18/704 - AŞS. 19/705 - AŞS. 20/706 - AŞS. 21/707 - AŞS. 22/708 - AŞS. 23/709 AŞS. 24/710 - AŞS. 25/711 - AŞS. 29/715 - AŞS. 45/731 - AŞS. 51/737 - AŞS. 56/742 AŞS. 60/746 - AŞS. 72/758 - AŞS. 76/762 - AŞS.79/ 765 - AŞS. 80/766 - AŞS. 93/779 AŞS. 123/809 - AŞS.126/812 - AŞS. 134/820 - AŞS. 141/827 - AŞS. 150/836 - AŞS. 159 - AŞS. 166/852 - AŞS. 179/865 - AŞS. 186/872 - AŞS. 187/873 - AŞS. 190/876 - AŞS. 192/878 - AŞS. 196/882 - AŞS. 207/893 - AŞS. 219/905 - AŞS. 240/926 - AŞS. 300/986 AŞS. 315/1001 - AŞS. 317/1003 - AŞS. 381/1067.

BOA. EV. MKT. CHT.189/63- BOA. EV. MKT. CHT. 22/71

VGM. Deft. 384/134 - VGM. Deft. 372/109 - VGM. Deft. 2624/35.

Akdağ, Mustafa. (1999). Türk Halkının Dirlik ve Düzenlik Kavgası- Celâlî İsyanları, Barış Yayınları, 2. Bs. Ankara.

Barkey, Karen. (1999). Eşkıyalar ve Devlet: Osmanlı Tarzı Devlet Merkezileşmesi, çev. Z. Altok, Tarih Vakfı Yurt Yayınları, İstanbul.

Ceyhan, Muhammed. (2012). Celâlî İsyanlarının Ankara Vakıf Gayrimenkulleri Üzerinde Yarattığı Tahribatın Tesbiti(Şer'iye Sicilleri Işı̆̆ında), Tarihte Ankara Uluslararası Sempozyumu Bildirileri I, Ankara, 359-376.

Çınar, Hüseyin. (2000). “1611-1612 Yıllarında Ankara'dan Bir Görünüm”, Kebikeç IX, Ankara, 97-122.

Ergenç, Özer. (1995). XVI. Yüzyılda Ankara ve Konya, Ankara Enstitüsü Vakfı Yayınları, Ankara.

Ertaş, M. Yaşar. (2009). 18 ve 19. Yüzyıllarda Osmanlı Taşrasında Yasadışılık: Yerel İdarecilerle Eşkıya İlişkisi, Osmanlıdan Günümüze Eşkıyalık ve Terör, (ed.) O. Köse, Samsun, 145-154.

Griswold, William J. (2000) Anadolu'da Büyük İsyan (1000-1021/1591-1611), çev. Ü. Tansel, İstanbul.

Göyünç, Nejat. (1979). “Hane Deyimi Hakkında”, Tarih Dergisi XXXII, 331-348.

Hobsbawm, Eric J. (1997). Eşkıyalar, Avesta Yayınları, İstanbul,

İlgürel, Mücteba. (1988). "Abaza Mehmed Paşa”, TDVİA. I, İstanbul, 11-12

İlgürel, Mücteba. (1995). “Osmanlılarda Eşkıya”, TDVİA. XI, İstanbul, 467-468.

İnalcık, Halil. (1980). Military and Fiscal in the Ottoman Empire(1600-1800), Archivum Ottomanicum VI, 283-337.

İnalcık, Halil. (1993). Osmanlı İmparatorluğu Klâsik Çă̆(1300-1600), çev. R. Sezer, Yap1 Kredi Yayınları, İstanbul

Kaya, Mustafa. (2013). XVIII. yüzyılda Yabanabâd Kazasında Görülen Kanunsuzluk Hareketleri, Ankara Araştırmaları Dergisi I(I), 51-65. 
Nagata, Yuzo. (1997). Tarihte Âyânlar Karaosmanoğulları Üzerine Bir İnceleme, Türk Tarih Kurumu Yayınları, Ankara.

Öz, Mehmet. (2009). Modernleşme Öncesinde Osmanlı Toplumunda Eşkıyalık Hareketlerinin Niteliği ve Özellikleri, Osmanlıdan Günümüze Eşkıyalık ve Terör, (ed.) O. Köse, Samsun, 33-40.

Özdemir, Rifat. (1986). XIX. Yüzyılın İlk Yarısında Ankara, Kültür ve Turizm Bakanlığ1 Yayınları, Ankara.

Özkaya, Yücel. (2014). Osmanlı İmparatorluğu'nda Âyânlık, Türk Tarih Kurumu Yayınları, 2. Bask1, Ankara.

Quataert, Donald. (2005). Osmanlı İmparatorluğu(1700-1922), çev. A. Berktay, İstanbul.

Soyudoğan, Muhsin. (2006). Devlet-Eşkıya İlişkileri Bağlamında Ayntab ve Çevresinde Aşiret Eşkıyalığı, Kebikeç, 21, Ankara, 147-174.

Söylemez, Faruk. (2007). “XVIII. yüzyıl Başlarından XIX. Yüzyıl Ortalarına Kadar Maraş ve Çevresinde Eşkıyalık Hareketleri”, Sosyal Bilimler Enstitüsü Dergisi XXII, 69-85.

Sun Tzu. (1971). The Art of War, London, New York: Oxford University Press.

Tabakoğu, Ahmet. (1985). Gerileme Dönemine Girerken Osmanl Maliyesi, Dergah Yayınları, İstanbul.

Taş, Hülya. (2006). XVII. Yüzyılda Ankara, Türk Tarih Kurumu Yayınları, Ankara.

Uluçay, M. Çağatay. (1944). XVII. Asırda Saruhan'da Eşkıyalık ve Halk Hareketleri, Resimli Ay Matbaası, İstanbul.

Uzun, Efkan. (2009). “Osmanlı Ülkesinde Görülen İsyan ve Eşkıyalık Olayları Karşısında Alınan Bazı Tedbirler Hakkında Bir Değerlendirme” Türklük Bilimi Araştırmaları XXV, 185-214.

Ünal, Mehmet Ali. (2011). Osmanlı Tarih Sözlüğ̈̈̈, Paradigma Yayınları, İstanbul.

Yediyıldız, Bahaeddin. (2003). XVIII. Yüzyılda Türkiye'de Vakıf Müessesesi, Türk Tarih Kurumu Yayınları, Ankara 
Ek. I: Ankara'da Celâlî Eşkıyası İle İlgili Hasan Paşa ve Yeğen Bey Vakıflarının Kayıtları(AŞS. 15/701: 53 ve 54)

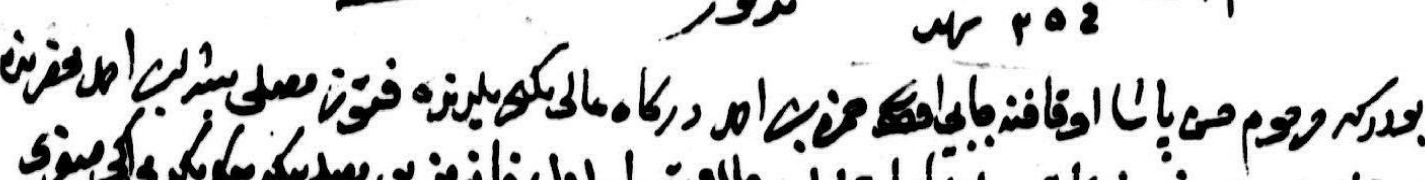

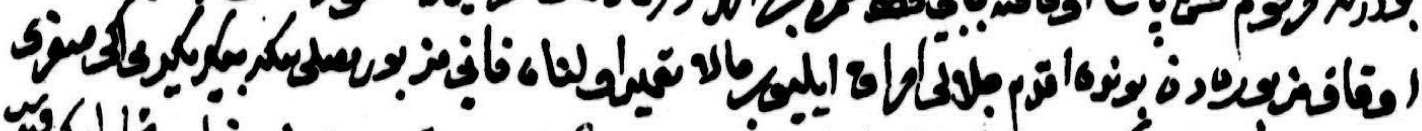

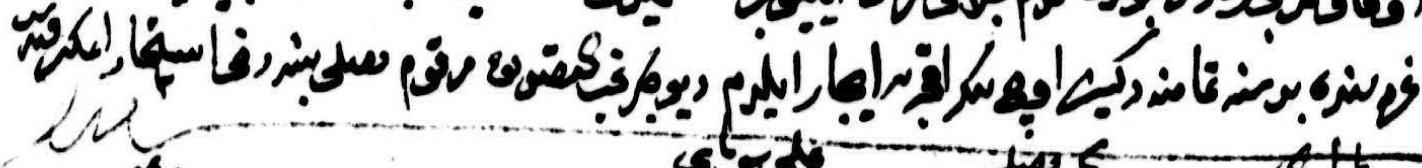

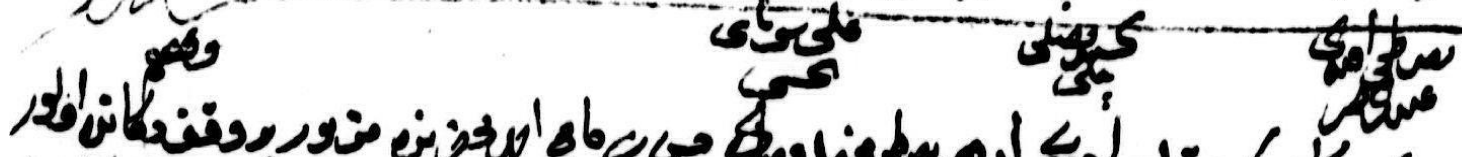

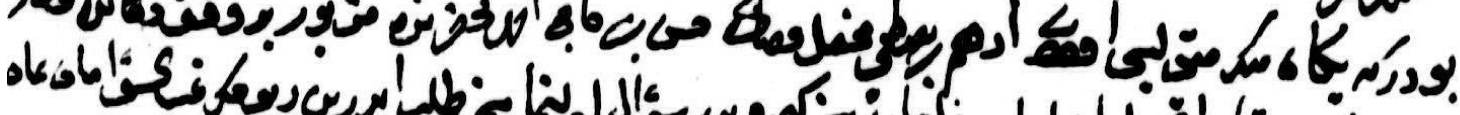

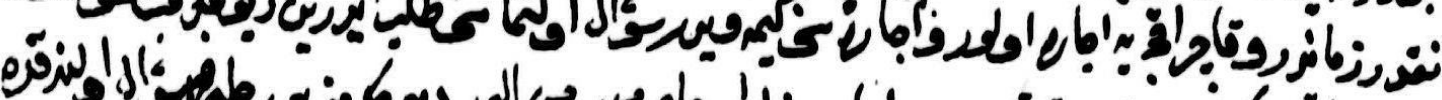

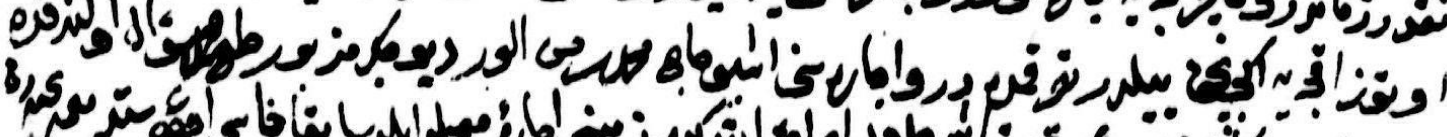

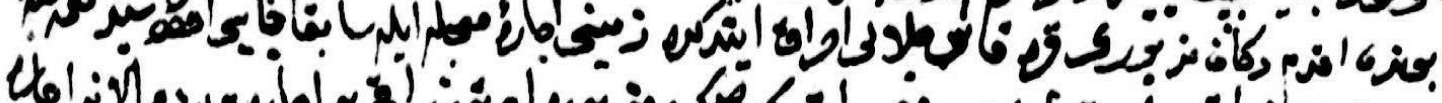

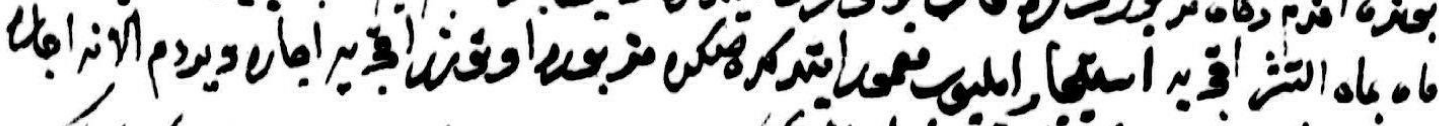

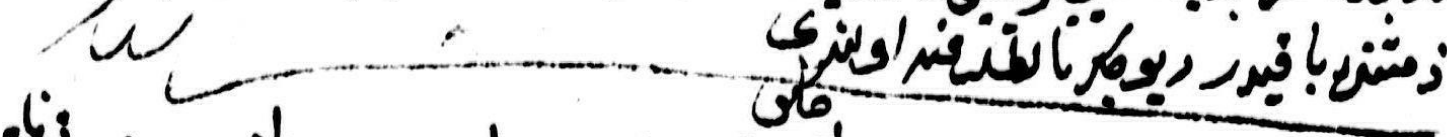

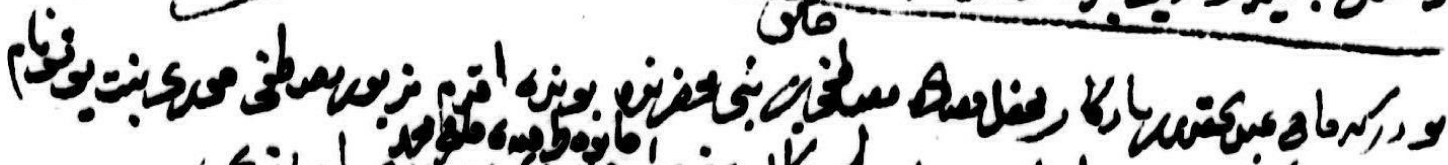

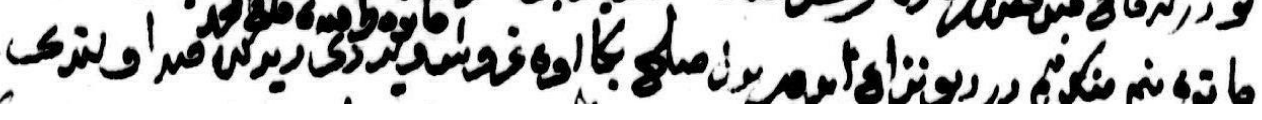

